\title{
Suprapto Suryodarmo's Silent Path a Documentary Film
}

\author{
Deny Tri Ardianto ${ }^{1}$, Bedjo Riyanto ${ }^{2}$, Putut Handoko Pramana ${ }^{3}$ \\ ${ }^{123}$ Desain Komunikasi Visual, Universitas Sebelas Maret, Surakarta, Indonesia \\ denytri@staff.uns.ac.id
}

\begin{abstract}
Dance films come in several genres, including: experimental, narrative, and documentary. Suprapto Suryodarmo's Silent Path is a documentary film that uses body movements as the narrative language to convey the messages or feelings in the film. Made with a performative approach (mode), this documentary tells the story of Suprapto Suryodarmo's daily life, of how he lives it and his efforts in responding to his environment through meditative movements as a form of self-approach to the Creator. The results of this film production are expected to add to the scientific repertoire in the area of documentary and dance films. After that, people will begin to learn values in behaving in life, such as politeness, manners, tolerance, and things that are culturally acceptable in the society, a stage which Suprapto refers as solah.
\end{abstract}

Keywords: dance film, movement, documentary film.

\section{A. INTRODUCTION}

A hall of a traditional Javanese house, quiet and tranquil, only a soft voice of gender, a resonance of Javanese rythmic instrument, filling the visual atmosphere that is present without much narration, a prelude to the following scene, a scene that takes place in the bedroom, Suprapto moves his hands slowly, rubbing his wrinkled face, followed by a bending gesture as if prostrating on the wooden bed. Acts after acts flow through the four scenes in four places where Suprapto spends his daily life. Such visuals set the opening of a biographical documentary film from a movement artist, Suprapto Suryodarmo.

The film Suprapto Suryodarmo's Silent Path (produced in 2018) is one of my dance films which were screened in a one month research and lectures series held in several campuses in Germany under the invitation of the DAAD (Deutscher Akademischer Austauschdienst). This research in Germany in 2018 is my second research regarding the themes of Cinematography, Movement and Dance. Previously, in 2009-2010, I had also conducted a literature research in Germany on Experimental Film and Dance Film. 


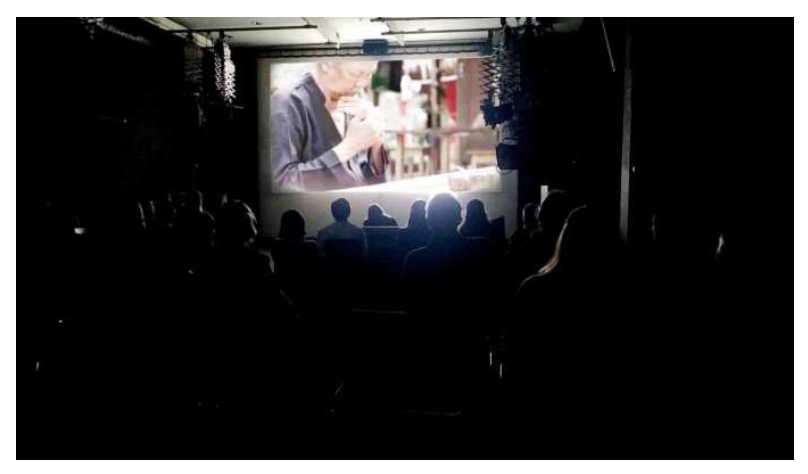

Figure 1. Screening of Suprapto Suryodarmo's Silent Path film in HBK Braunschweig, Germany (2018)

Speaking of movement and dance, Suprapto Suryodarmo is a Javanese movement artist and a guru who has thousands of followers around the world. With one footing in the world of art and the other in the world of mysticism, Suprapto Suryodarmo (born 1945) reinterprets the traditions of performing arts, philosophy, and the Javanese myths, that are influenced by the Indian culture. He does the interpretation in structured improvisations designed to increase self-awareness and harmonize the participants with the environment and the world that they live in. Despite having close relations with many prominent Indonesian performing artists, he is also a controversial figure in his own country, especially in Central Java, where he is known as the Begawan Polah, the eccentric high priest of movement[1].

\section{B. METHOD}

In each of his teachings, Suprapto always interprets that what he does is as if a process of rebirth, where he feels as a newborn loking for a position in his life in the world. This is consistent with his belief that people are born through the processes of obah, polah, olah, solah, and joged.

Obah is when a baby is born, that he will move according to his instinct, without knowing what he wants. Polah is when someone moves more intensely and does not know what he desires. Then the phase when someone already knows what he wants and is able to manage his own movements or behavior is referred to as olah. After that, people will begin to learn values in behaving in life, such as politeness, manners, tolerance, and things that are culturally acceptable in the society, a stage which Suprapto refers as solah. Whereas the final process, when someone has been able to improvise, think and process for the things to come, or to position himself in all situations, as well as to express himself, is referred to as joged. Someone is referred to as a whole person if he has reached the five levels above.

Suprapto himself prefers to position himself at the obah phase, a fundamental position where intuition is more dominant. Intuition is a term for the ability to understand something without going through rational and intellectual reasoning. It seems that understanding suddenly comes from another world and is beyond consciousness[2]. In a simpler sense intuition can be interpreted as the ability to gain knowledge or direct understanding without interruption of rational thought intrusion or logical interference [3]. Suprapto wants to be like an innocent 
baby, without being burdened with all of the problems in the world, moving freely, shouting, and expressing nullifying the rhythm, tempo, and all the rules that are usually present in dance. According to him, movement is a more accurate description of his artistic activities, rather than dance[4].

\section{RESULT AND DISCUSSION}

\section{Decumentary Film}

The documentary film Suprapto Suryodarmo's Silent Path presents Suprapto's daily life, in which with each gesture he builds a rhythm without a sound, only the flowing body movements responding to any changes in the surrounding environment. For Suprapto, the body is a medium of art, a medium for speech, and an effort to get closer to the Creator. The soft or fast tempo movements and the changes in facial expression are his responses to the environment, and that is where he can find the communication point with his self, nature, and the Creator.

As a documentary, Suprapto Suryodarmo's Silent Path applies a performative mode. Performative documentaries emphasize the involvement of the filmmaker with the film subject. The filmmaker shows greater political or historical reality through a window of his experience. Instead of relying on the expository approach and persuasion rhetorics, a director who employs a performative mode becomes a guide that shows and presents the narratives with the honest emotions he is feeling. In performative mode, filmmakers provide a perspective of "what it feels like to be there", on something (world, culture, or historical events) that the audience may or may never have known[5]. Stella Bruzzi in his book New Documentary: A Critical Introduction (2000) stated that performative mode provides a wider space for creative freedom in the form of visual abstraction, narrative and so on[6].

In this film I do not want to interfere the audience with narratives in the form of voice over, texts, interviews, etc., which may cause the audiences' concentration to split when watching the movements in the film. Suprapto's gestures, movements and expressions are very descriptive, story-telling and explaining many things. It will certainly be most unfortunate if intervened with other things that are thought to be able to add or clarify information from the film. I let the visuals take over the audiences' attention to the film.

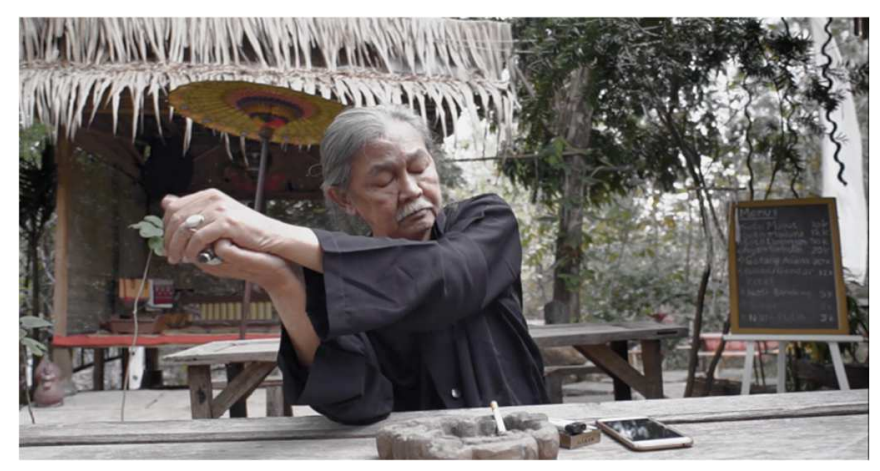

Figure 2. Screenshot of Suprapto Suryodarmo's Silent Path film (2018) 
Movements have a metaphorical power that it is able to present various ideas that cannot be constructed by words. Especially if the movements are related to camera technology and editing, in which the camera and editing can create a 'new world', an imaginative universe that seems real. This power is presented by dance films so that they can penetrate the limitations of a stage. Through the camera, the world (space) is created and limited by frames, with various angle techniques or viewpoints and movements, the camera can direct the viewer's point of view in seeing the designed universe. While through the stage, the world (space) extends wide and the audiences are free to determine their perspective. In this context, dance films have the advantage to focus the audiences' point of view on a particular world (space).

The development of film and video technology has had a tremendous impact on the creation of dance films. Dance and film have developed, creating a hybrid of art into a separate genre known as dance film, both of which are present in the packaging of short and long films, experimental films, music videos, documentary films, and other types of films .

David Rousseve, a professor in the field of choreography and performance from the University of California, Los Angeles (UCLA) in his e-mail, wrote that dance films or dance for the camera have various meanings depending on the perspective of each person. According to Rousseve, Dance film, departing from his perspective as a dance film director and choreographer, is a choreography made specifically for camera needs, not for the stage needs of a show, a dance that is created and can only be presented in a film medium . Rousseve also added that outside of the dance film genre, an intersection between dance and video or film medium could be found in the form of performance documentation or documentary films[7].

The form of dance films that I present in this documentary film is dominated by visuals that will draw in audiences' attention when following the flow of the film which initially runs slowly then gets faster and finally slows down again[8]. The musical instrument in the form of gender gamelan is presented in the film's initial scene, when Suprapto starts the day, from the bedroom, living room and front porch of the house. The overall atmosphere built in this film takes the form of original or natural ambience without the intervention of musical illustrations and sound effects commonly used in films[9][10]. According to Suprapto, the silence in this film seems to expose him, because in his current age which has now reached the seventies, he always feels lonely, even in the crowd. When he looks at his surroundings, sometimes he feels that everything is running very slowly (in a slow motion). He responds to this with meditative movements that are soft and flowing beautifully, seeming very expressive and effortless.

\section{CONCLUSSION}

Visuals have the power to communicate messages. When movement and dance are presented in a documentary to present a narrative or story, an understanding of the concept of dance film creation should be established. Because the most important thing is not the format of the medium, but for every person engaged in dance film/video creation to be challenged to find new narrative languages through screen films or cinema and television. In addition to concepts or ideas, an understanding regarding the steps in dance film production is also needed. One of which is on creating good and intense cooperation between filmmakers and choreographers, dance or movement presenters and the work mechanism of the supporting tools for film production, such as cameras, voice recorders, lighting and so on. Because what is created is not only about creating a dance, or a video of a dance, but finding or communicating ideas that 
can only be expressed through a combination of the two mediums namely dance and video. The unique style and structure found in both mediums will create special characteristics.

\section{REFERENCES}

[1] Prince, P. Cohen, Matthew Isaac. Suprapto Suryodarmo: Art Ritual In Out. Seleh Notes 15, (2). pp.4-6. Royal Holloway, University of London. 2008.

[2] Yusa, I Made Marthana. Sinergi Sains, Teknologi Dan Seni: Dalam Proses Berkarya Kreatif Di Dunia Teknologi Informasi. Bali: STMIK STIKOM INDONESIA-Panjer, Denpasar Selatan. 2016.

[3] Sadler-Smith, Eugene and Erella Shefy. The intuitive executive: Understanding and applying 'gut feel' in decision-making. Academy of Management Executive UK, Vol. 18 (4). 2004.

[4] Antoinette, Michelle. "Endurance and Overcoming in the Art of Amron Omar and Melati Suryodarmo: Invoking Uncommon Alignments for Contemporary Southeast Asian Art History". Southeast of Now: Directions in Contemporary and Modern Art in Asia, Vol. 1 (1), 2017.

[5] Nichols, Bill. Introduction to Documentary, Third Edition. USA: Indiana University Press Bloomington. 2017.

[6] Bruzzi, Stella. New Documentary: A Critical Introduction. London and USA: Roudledge. 2000.

[7] Rousseve, David. "Dance Film and Dance for the Camera". In interview with Deny Tri Ardianto. 12 February 2012.

[8] Suryodarmo, Suprapto. "One Lesson from The Garden". In interview with Deny Tri Ardianto, August 2018.

[9] Sørensen, I. E. Crowdsourcing and outsourcing: the impact of online funding and distribution on the documentary film industry in the UK. Media, Culture \& Society, 34(6), 726-743. 2012.

[10] Lin, S. J. Perceived impact of a documentary film: An investigation of the first-person effect and its implications for environmental issues. Science Communication, 35(6), 708733. 2013. 